

\section{Issues and Trends in Interdisciplinary Behavior and Social Science}

\section{Editors}

Ford Lumban Gaol

Bina Nusantara University, Indonesia

Fonny Hutagalung \& Fong Peng Chew

University of Malaya, Malaysia 
CRC Press/Balkema is an imprint of the Taylor \& Francis Group, an informa business

(C) 2018 Taylor \& Francis Group, London, UK

Typeset by V Publishing Solutions Pvt Ltd., Chennai, India

Printed and bound in Great Britain by CPI Group (UK) Ltd, Croydon, CR0 4YY

All rights reserved. No part of this publication or the information contained herein may be reproduced, stored in a retrieval system, or transmitted in any form or by any means, electronic, mechanical, by photocopying, recording or otherwise, without written prior permission from the publisher.

Although all care is taken to ensure integrity and the quality of this publication and the information herein, no responsibility is assumed by the publishers nor the author for any damage to the property or persons as a result of operation or use of this publication and/or the information contained herein.

Published by: CRC Press/Balkema

Schipholweg 107C, 2316 XC Leiden, The Netherlands

e-mail: Pub.NL@taylorandfrancis.com

www.crcpress.com - www.taylorandfrancis.com

ISBN: 978-1-138-55380-4 (Hardback)

ISBN: 978-1-315-14870-0 (eBook)

Universitas Islam Negeri Sunan Kalijaga (05.07.2019) 


\section{Table of contents}

Preface

Committees

The opportunities and strengths of Thailand's MICE industry

Y. Sudharatna \& P. Chetthamrongchai

Evaluation of the differentiating factors in the avocado value chain

J.A. Martínez-Arroyo \& M.A. Valenzo-Jiménez

Competitiveness in the handicraft sector in Mexico

M.A. Valenzo-Jiménez, J.A. Martínez-Arroyo \& L.A. Villa-Hernández

Higher-order thinking skills in teaching the Malay language through questions and questioning among the teachers

F.P. Chew, Z.H. Hamad \& F. Hutagalung

Using poems to increase phonological awareness among children

C.T. Lim \& F. P. Chew

Web-based catering marketplace business plan: Cateringku.com

B. Susanto, F. Lumban Gaol, S. Si \& M. Kom

Practice of mobile guide and learning system by GPS positioning technology

K.-Y. Chin, H.-Y. Hsiao \& Z.-W. Hong

Mathematical models for the spread of rumors: A review

M.Z. Ndii, E. Carnia \& A.K. Supriatna

Relationship between emotional intelligence and job performance among early childhood professionals: A preliminary study

N. Ghanieah, F. Hutagalung, N.A. Rosli \& C.H. Leng

Russian partnership banking integration in Islamic financial system

N.F. Yalalova \& A.A. Daryakin

Influencing factors of ethnic tolerance among multiethnic youths

A.R. Ahmad, A.A.A. Rahman, M.M. Awang \& F.P. Chew

Analysis of innovation cluster formation in industrially developed countries

I.M. Ablaev

An approach to developing a programmer competency model in Russia

L.V. Naykhanova, N.B. Khaptakhaeva, N.N. Auysheeva \& T.Y. Baklanova

Organizational behavior norms as a factor boosting the emotional stability of staff at housing and utility services enterprises

M.D. Mironova, R. M. Sirazetdinov \& M.Y. Virtsev

Methodology for the technical and economic analysis of a product

at the projection stage

V.N. Nesterov \& N.N. Kozlova 
Parental challenges in the filial therapy process: A conceptual study

C.C. Han, D.-L. Baranovich, L.P. Li \& F. Hutagalung

Report on the results of a monitoring study conducted in the Russian Federation on the prevention of addictive and suicidal behavior and internet risks among adolescents

A.V. Khydyrova, N.A. Mamedova \& E.G. Artamonova

Assessment of the quality of language education of future kindergarten teachers

I.N. Andreeva, T.A. Volkova, M.R. Shamtieva \& N.N. Shcheglova

Developing design and construction of backspin serving skill tests to assess

the learning outcomes for table tennis serving skills

Sumaryanti, Tomoliyus, Sujarwo, B. Utama \& H.M. Jatmika

Marketing management of Madrasah Ibtidaiyah (MI)

E. Munastiwi

Development of competitiveness as a condition of professional demand

for graduates of pedagogical directions

K. Yu. Badyina, N.N. Golovina, A.V. Rybakov \& V.A. Svetlova

Development of students' fire safety behavior in the school education system

V.V. Bakhtina, Zh.O. Kuzminykh, A.G. Bakhtin \& O. A. Yagdarova

Development and enhancement of communication for junior school children with vision impairments

E. Y. Borisova, O.V. Danilova, T.A. Karandaeva \& I. B. Kozina

Neuropsychological approach to the correction of developmental deviations of preschool children with health limitations

E. Y. Borisova \& I. B. Kozina

Active and interactive methods for teaching psychological counseling

I.E. Dremina, L.V. Lezhnina, I.A. Kurapova \& S.V. Korableva

Superstitions as part of the frame "pregnancy and birth" in the English, Russian, and Mari languages: Postliminary level

E.E. Fliginskikh, S.L. Yakovleva, K Y. Badyina \& G.N. Semènova

Functional problems of the tourism development institutions

G.F. Ruchkina, M.V. Demchenko, N. Rouiller \& E.L. Vengerovskiy

Formation of students' readiness for safe behavior in dangerous situations

M.N. Gavrilova, O.V. Polozova, S.A. Mukhina \& I.S. Zimina

A poetics of Mari verbal charms

N.N. Glukhova, E.V. Guseva, N.M. Krasnova \& V.N. Maksimov

The trends in the dynamics of Mari ethnic values

N.N. Glukhova, G.N. Boyarinova, G.N. Kadykova \& G.E. Shkalina

On the importance of comparative phonetic analysis for bilingual language learning

I. G. Ivanova, R.A. Egoshina, N.G. Bazhenova \& N.V. Rusinova

Resource of a public debt in forecasting the development of the economy

M.V. Kazakovtseva \& E.I. Tsaregorodtsev

Conceptual theories of forming leadership qualities of a competitive university student

S. Y. Lavrentiev, D.A. Krylov \& S.G. Korotkov 
The problem of early development of creative abilities via experimentation in productive activities

O.A. Petukhova, S.L. Shalaeva, S.O. Grunina \& N.N. Chaldyshkina

A negative assessment of the concept insolvency in French and English paroemias

T.A. Soldatkina, S.L. Yakovleva, G.N. Kazyro \& G.L. Sokolova

Training of the Russian Federation's national guard officers in information security

R.V. Streltsov, T. A. Lavina, L.L. Bosova \& E.I. Tsaregorodtsev

Models of the learning styles within the adaptive system of mathematical training of students

V.I. Toktarova

The problem of realizing administrative responsibility for an offence provided in Article 19.21 of the administrative code of Russian Federation

A.V. Vissarov, A.M. Gavrilov, V.V. Timofeev \& A.A. Yarygin

Grant-supported collaboration between specialists and parents of children with special psychophysical needs

O.P. Zabolotskikh, I. A. Zagainov, M.L. Blinova \& O.V. Shishkina

Preparing university educators for tutoring adult learners in distance education

N.A. Biryukova, D.L. Kolomiets, V.I. Kazarenkov \& I.M. Sinagatullin

Theoretical analysis of the rehabilitation study of children with limited health capacities

J.A. Dorogova, O.N. Ustymenko, E.A. Loskutovan \& N.V. Yambaeva

Analysis of tourism management development of the Bunaken National Marine Park

S.B. Kairupan \& R. H.E. Sendouw

A three-stage data envelopment analysis combined with artificial neural network model for measuring the efficiency of electric utilities

P.M. Kannan \& G. Marthandan

Emotional change of immigrant youths in Korea after collage art therapy: A case study G. Wang, Y. Kim \& Y. Oh

A study on the "individual accountability" of undergraduate students in the cooperative léarning-centered liberal education class

Y. Kim, G. Kim \& H. Choi

Effect of competency on the job performance of frontline employees in Islamic banks:

The moderator effect of religiosity

M.F.B. Hamzah \& M.N.B.Md. Hussain

Role of communication in IT project success

K. Shasheela Devi, G. Marthandan \& K Rathimala

Pupils' self-regulated skills in relation to their perceived position in formal and informal school life processes

\section{K. Hrbackova}

Author index 


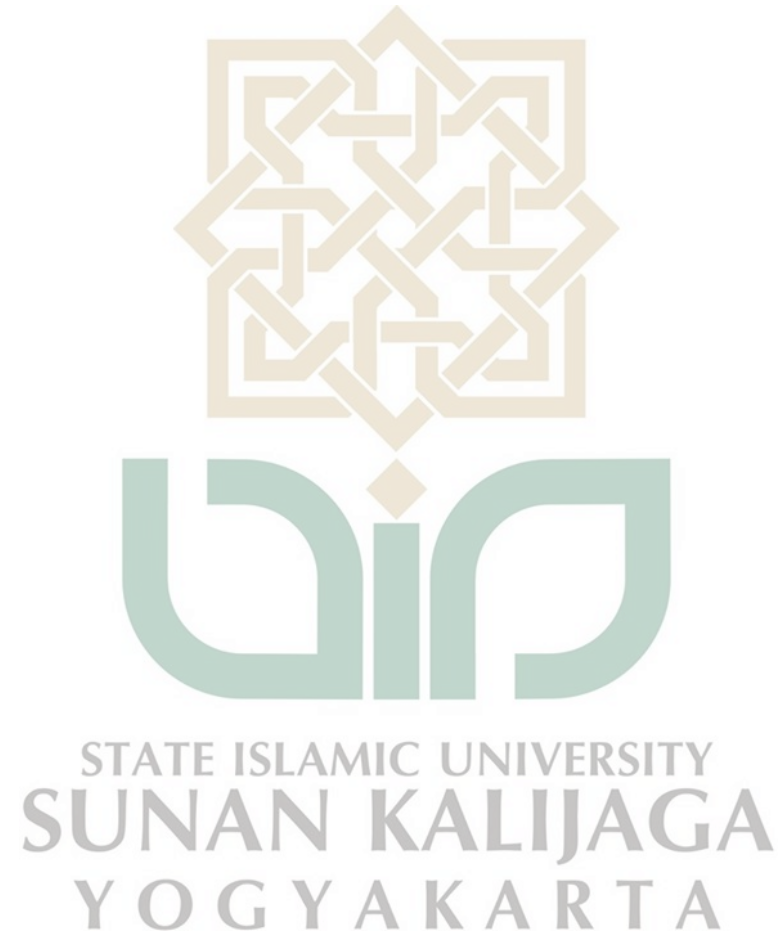




\section{Preface}

The theme of the 6th International Congress on Interdisciplinary Behavior \& Social Science 2017 was "The Role of Social Sciences in Cross-Cutting Issues in Humanities".

In cross-cutting issues of broad relevance, Social Sciences and Humanities are fully integrated to enhance industrial leadership and to tackle various societal challenges. ICIBSoS 2017 provided the economic and social analysis necessary for reforming such Humanities issues as education, sociology, anthropology, politics, history, philosophy and psychology as well as food security.

Contributions to ICIBSoS 2017 give necessary insight into the cultural and human dimension of such diverse research areas as transport, climate change, energy and agriculture. ICIBSoS 2017 also analyses the cultural, behavioural, psychological, social and institutional changes that transform people's behaviour and global environment.

ICIBSoS 2017 proposes new ideas, strategies and governance structures for overcoming the crisis in the global perspective, innovating the public sector and business models, promoting social innovation and fostering creativity in the development of services and product design.

One example that was discussed at ICIBSoS 2017 was the evolution from the concept of Ecosystem that adapts the framework to the Millennium Ecosystem Assessment Nature's Contributions to People classification assessments. Issues such as sharing economics and the economics of disruptive technology were also discussed at ICIBSoS 2017.

Hence, at ICIBSoS 2017, there was a discussion about new paths that have to be forged, including revisiting basic ontological and epistemological considerations, such as how we understand the world, what knowledge is, and the role of science. Constructive interdisciplinary dialogues in support of the development of innovative frames and terminologies have become the goal of and contribution by ICIBSoS 2017.

Finally, we hope that this book will make a significant contribution to the social sciences and humanities.

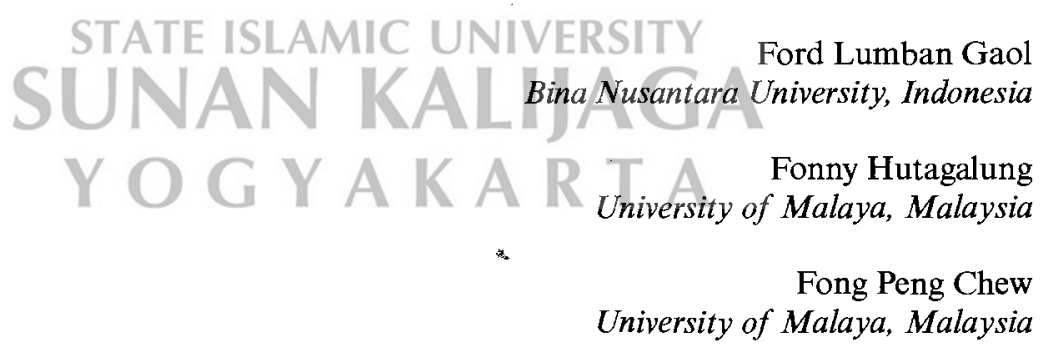




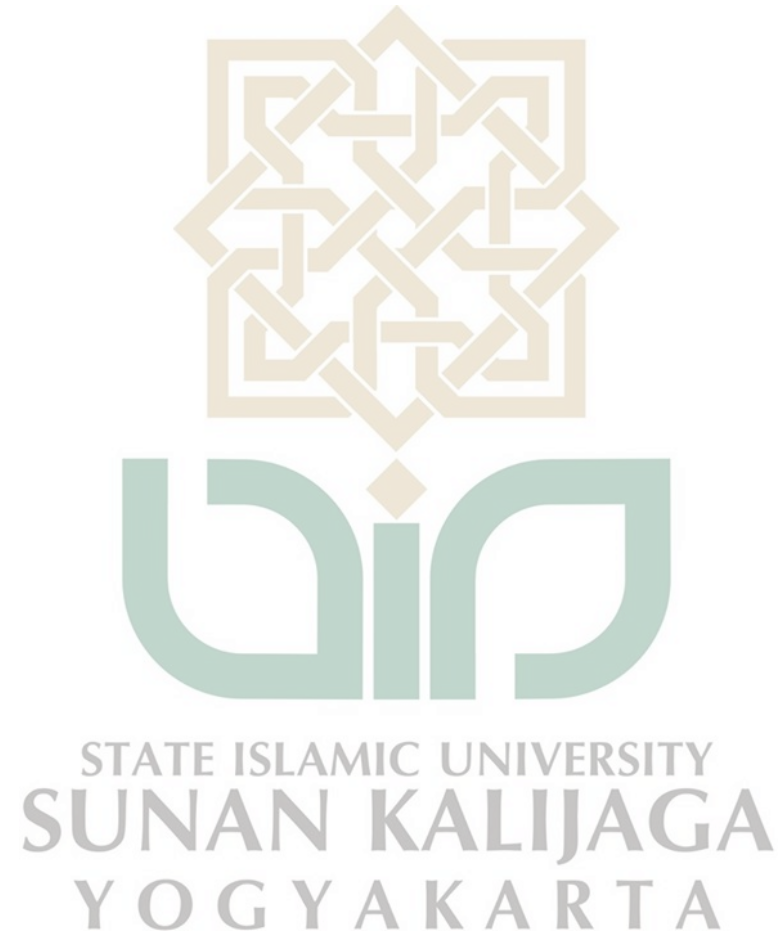




\section{Committees}

\section{CONFERENCE CHAIR}

Fonny Hutagalung - University of Malaya, Malaysia

Wayne Marr-University of Alaska, USA

Ford Lumban Gaol-IEEE, IAIAI, \& SERSC, Indonesia

\section{PROGRAM COMMITTEE CHAIR}

Validova Asiya Faritovna-Kazan Federal University, Russia

Varlamova Julia Andreevna-Kazan Federal University, Russia

Larionova Natalia - Kazan Federal University, Russia

Malganova Irina G.-Kazan Federal University, Russia

Odintsova Julia L.-Kazan Federal University, Russia

A.J.W. Taylor-Victoria University of Wellington, New Zealand

Maria de Lourdes Machado-Taylor-Taylor Center for Research in Higher Education Policies (CIPES), Portugal

Seifedine Kadry - Lebanese University, Labanon

\section{PUBLICATION CHAIR}

N. Panchuhanatham-Annamalai University, India

\section{PUBLICITY CHAIR}

N. Panchanatham Annamalai University, India

T. Ramayah-Universiti Sains Malaysia, Malaysia

Yousef Farhaoui-Moulay Ismail University, Morocco

\section{PROGRAM COMMITTEES}

Valentinas Navickas - Kaunas University of Technology, Lithuania Hsin Rau-Chung Yuan Christian University, Taiwan

Panos M. Pardalos-University of Florida, USA

Siham El-Kafafi_-Manukau Institute of Technology, New Zealand

T.C. Edwin Cheng - The Hong Kong Polytechnic University, Hong Kong

Baldev Raj-Indira Gandhi Centre for Atomic Research (IGCAR), India

Yuosre Badir-Asian Institute of Technology, Thailand

Maria Fekete-Farkas - Szent István University, Hungary

Hong Yan-Hong Kong Polytechnic University, Hong Kong

Qi Yu-Rochester Institute of Technology, USA 
Tatsiana N. Rybak-State Economic University, Republic of Belarus

Lalit Mohan Patnaik - Indian Institute of Science, India

Janardan Nanda-Indian Institute of Technology, Delhi, India

Nazmi Sari-University of Saskatchewan, Canada

Md. Ghulam Murtaza-Bangladesh Khulna University, Bangladesh

Wan Khairuzzaman Wan Ismail--International Business School (UTM IBS), Malaysia

Ha In Bong-School of Economics and Trade, Korea

Hui Tak Kee - National University of Singapore, Singapore

Andrew Rosalsky-University of Florida, USA

Jennifer Chan Kim Lian-University Malaysia Sabah, Malaysia

Celso Ribeiro-Universidade Federal Fluminense, Brazil

Sajid Anwar--University of the Sunshine Coast, Australia

Pradyot Jena-Institut für Umweltökonomik und Welthandel, Germany

Wayne Marr University of Alaska, USA

Siti Zaleha Abdul Rasid-International Business School (UTM IBS), Malaysia

K.L. Mak-Hong Kong University, Hong Kong

Maria de Lourdes Machado-Taylor-Taylor Center for Research in Higher Education Policies (CIPES), Portugal

A.J.W. Taylor-Victoria University of Wellington, New Zealand

Yuelan Chen--Economist Consultant, Australia

Jens Graff-SolBridge International School of Business, Woosong Educational Foundation, South Korea

Chandana Withana-Charles Sturt University, Sydney, Australia

Will Hickey--SolBridge International School of Business, Woosong Educational Foundation, South Korea

Constantinos J. Stefanou-ATEI of Thessaloniki, Greece

N. Panchanatham--Annamalai University, India

Binnur Yeşilyaprak-Ankara University, Turkey

Athanassios Vozikis--University of Piraeus, Greece

Marina Riga-University of Piraeus, Greece

Haretsebe Manwa-North West University, South Africa

Javier de Esteban Curiel-Rey Juan Carlos University, Spain

Arta Antonovica--University Rey Juan Carlos, Spain

George M. Korres--University of the Aegean, Greece

Zhou Xu--The Hong Kong Polytechnic University, Hong Kong

Sola Fajana-University of Lagos, Nigeria

Kate Daellenbach - Victoria University of Wellington, New Zealand

Brij Mohan -Louisiana State University, USA

Ian Hunt-Flinders University, Australia,

Ramadhar Singh--Indian Institute of Management Bangalore, India

Raymond K.H. Chan-City University of Hong Kong, Hong Kong

Anek R. Sankhyan-President Palaeo Research Society, India

T. Wing Lo City University of Hong Kong, Hong Kong

Jerzy Golosz--Jagiellonian University, Poland

Leonid Perlovsky-Air Force Research Laboratory, USA

Sheying Chen-Pace University, USA

Antonio Marturano-Catholic University of the Sacred Heart, Italy

Eric Chui--The University of Hong Kong, Hong Kong

Wenceslao J. Gonzalez-University of A Coruña, Spain

Maduabuchi Dukor-Nnamdi Azikiwe University, Nigeria

Rajendra Badgaiyan - University at Buffalo, USA

Robert J. Taormina--University of Macau, China

Rabia Imran Dhofar University, Oman

Validova Asiya Faritovna-Kazan Federal University, Russia

Universitas Islam Negeri Sunan Kalijaga (05.07.2019) 
Varlamova Julia Andreevna-Kazan Federal University, Russia Larionova Natalia-Kazan Federal University, Russia

Malganova Irina G.-Kazan Federal University, Russia

Odintsova Julia L.-Kazan Federal University, Russia

Chew Fong Peng-University of Malaya, Malaysia

Aishah Rosli-University of Malaya, Malaysia

Zulkifli Md Isa-University of Malaya, Malaysia

Kusmawati Hatta-University of Ar-Raniry-Aceh, Indonesia

Zulkefli Mansor-University of Kebangsaan Malaysia, Malaysia

Mohd Rushdan Abdul Razak - Open University, Malaysia

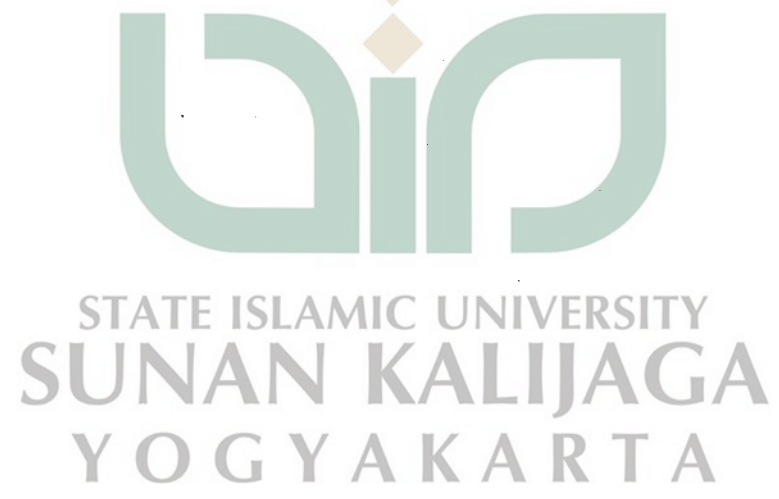




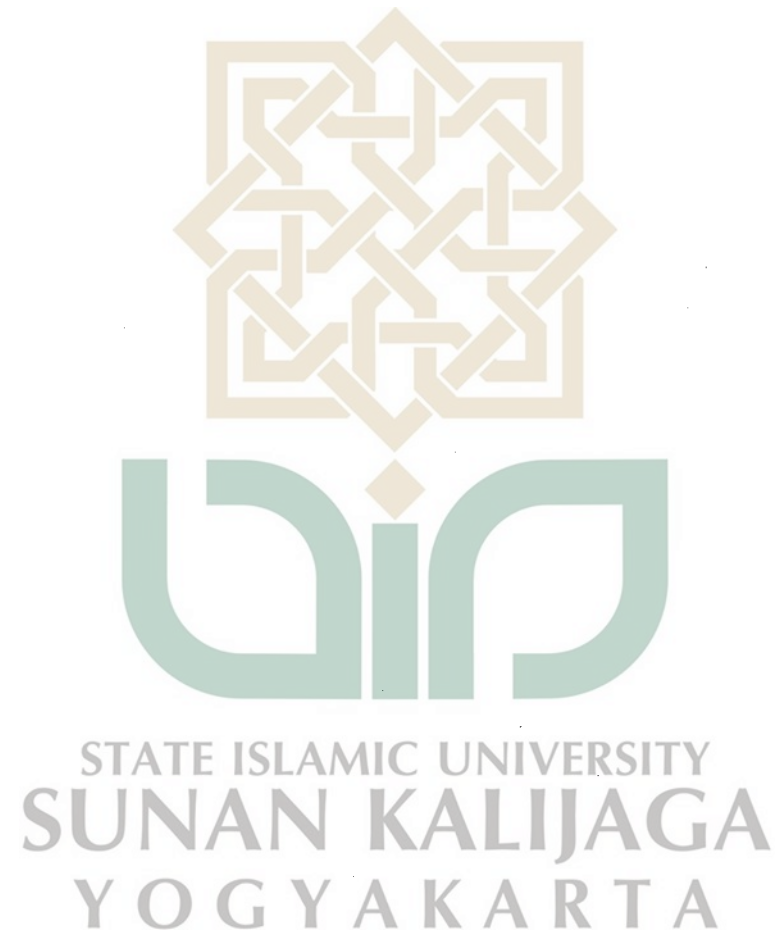




\title{
Marketing management of Madrasah Ibtidaiyah (MI)
}

\author{
Erni Munastiwi \\ State Islamic University, SunanKalijaga Yogyakarta, Indonesia
}

\begin{abstract}
The purpose of this study is to review the institution of special education of madrasah institutional management. Here, we focus on marketing management of madrasah institutions. Institutional marketing is one part of the management of educational institutions. Therefore, the management of madrasah marketing must be handled properly so that the objectives of the madrasah can be achieved. We hope that well-managed madrasah institutions will be well known for marketing and then the madrasah will be known and trusted by the community. Thus, the interest of the community is high against the madrasah. In this study, we use qualitative method with five madrasah research objects, five principals, five madrasah teachers, five members of the madrasah committee, and five madrasah parents. The data collection process includes (1) identifying participants, (2) gaining access to participants and places, (3) compiling the type of information that will answer the research question, (4) designing instruments to collect and record interview results, and (5) interpreting the collected data. The data collection method involves observation, interview, documentation, and audiovisual materials. Data analysis takes place before, during, and after field study. The results of this study show that madrasah education institutions are advised to manage marketing well. Madrasah marketing strategy is done consistently. In the context of education, marketing mix strategy can be used to win the competition, in this case, known as 7P (product, price, promotion, place, people, physical evidence, and process.) Madrasah marketing management implementing the marketing mix strategy can change the image of the community to the madrasah.
\end{abstract}

Keywords: marketing management, madrasah ibtidaiyah

\section{INTRODUCTIONSTATE ISLAMIC}

Madrasah is a formal educational institution under the guidance of the Ministry of Religious Affairs, while the school is a formal educational institution under the guidance of the Ministry of Education and Culture. The Law of the Republic of Indonesia Number 20 the Year of 2003, Article 17, Paragraph 2 stated that primary education in the form of elementary school (SD) and madrasah ibtidaiyah/Islamic elementary school (MI) are equal. In its development, both institutions experience problems. The government has regulated it in the Law of the Republic of Indonesia Number 20 Year 2003 regarding National Education System, which stated that there is an opportunity for madrasah to improve its quality and introduce itself in the middle of society. Constitutional madrasah has equality with other public schools. Nevertheless, the reality is that the community positioned the madrasah as a second choice. Madrasahs are considered less qualified schools, graduates from which are less able to compete in continuing higher education. This condition proves that madrasahs are difficult to become the primary educational institution of society. We address the question of how to manage a madrasah into a community-chosen institution. Madrasahs are no longer underestimated. Madrasahs are in line with other public schools. Therefore, the intent of the researcher is to overcome the condition through improving the management of institutions in general and marketing management in particular. The low public interest in madrasah is due to the 
management of madrasah, which is still managed traditionally, but not yet implemented in the optimal management function. To increase community interest, madrasah management must be addressed. Madrasahs and managers must change themselves to achieve educational goals. In addition to institutional management, the leadership of the institution has not met the qualifications as an educator. Another problem is financing. Thus, managers of madrasah institutions should examine more in the management of madrasah. To attract high public interest to madrasah, it is necessary to establish policies related to marketing management program of madrasah. Philip Kotler (1997: 36) states that customer satisfaction is a function of the impression of performance and expectations. If performance is below expectations, customers will not be satisfied, and vice versa. Furthermore, if performance exceeds expectations, the customer will be very satisfied or happy. In line with that Philip Kotler, Imam Machali (2017: 226) concluded that the madrasah as an educational service industry faces challenges; on the one hand, madrasah should strive to improve the quality and competence of graduates so as to meet the expectations of stakeholders, and on the other hand, madrasah is still seen as a second-class institution. Therefore, the madrasah should meet customer satisfaction. On the basis of the results of direct observation, generally people choose public education. The reality in the field is that the results of research on marketing management madrasah are less socialized to the community, especially managers of madrasah, teachers, and stakeholders. In addition, funding or financing issues are one of the factors causing inefficiency of madrasah marketing program. Another problem, lack of knowledge about marketing management, resulted in the competence of human resources of madrasah managers. In-depth examination of the marketing management of madrasahs will deepen and expand marketing knowledge. For practitioners, managing educational institutions get institutional management guidance. Similarly, policy makers have a basis for deciding policies. Researchers can improve the results of research to obtain accurate results. Students participating in research will get new experiences so as to acquire more knowledge and experience.

\section{METHODOLOGY}

In this study, we use qualitative method. The data collection process involves (1) identifying participants and places; (2) gaining access to participants and places; (3) compiling the type of information that will answer the research question; (4) designing instrument to collect and record interview result; and (5) implementing the collected data. The data collection method involves observation, interviews, documentation, and audiovisual materials (John Creswell, 2015: 420). Data analysis takes place before, during, and after field study. Field study was conducted according to Miles and Huberman (1984). The data were validated using member checking and triangulation.

\section{RESULTS AND DISCUSSION}

Madrasah is Islamic-based educational institution, which manages various levels of educational units from kindergarten (RaudhatulAthfal (R.A.)). The basic education unit is called Madrasah Ibtidaiyah (M.I.), while the level of junior secondary education unit called Madrasah Tsanawiyah (M.Ts.). The upper middle level is called Madrasah Aliyah (M.A.). "Madrasah" educational institutions began to flourish in Indonesia in the nineteenth century. This development began with the establishment of Madrasah Adabiyah by Abdullah Ahmad in Padang Panjang (Malik Fajar, 1999: vii). During its emergence, the madrasah focused more on Islamic religious learning. Together with its development, various problems aroused. Madrasahs had difficulty competing with public schools and were less desirable educational institutions for the public. Madrasah became the number two institution after public school. Lack of public interest due to the management of madrasah institutions has not been optimal. However, competition in education is inevitable. Several madrasah 
institutions are combined because of the shortage of students. Understanding the concept of marketing management depends on understanding the concept of the market.

The marketing process is a transactional process between producers and consumers together assigning agreed rewards. As an education management institution, madrasahs should determine marketing strategies related to educational services that satisfy customers. Thus, the impact of madrasah is better known to the public. According to Sheila (1996: 25), customer satisfaction has become an important part of marketing strategy and has greater strength than an advertisement. Customer satisfaction can also be an indicator of the quality of services provided, so that the increase and decrease in income can be seen from the extent of customer satisfaction, which depends on various elements: (1) matching of customer expectations and reality; (2) satisfaction with the service received; (3) financing affordable service programs as agreed between the customer and the madrasah; and (4) the existence of a conducive madrasah atmosphere. Customer satisfaction depends on the strategy used. The marketing strategy in question is the marketing mix (marketing mix). According to Kotler et al. (2002: 9), marketing mix is a set of controllable, tactical marketing tools that the firm integrates to produce the desired result in the target market. There are seven marketing mixes: (1) product, (2) price, (3) place, (4) promotion, (5) human resources, (6) physical evidence, and (7) process. With regard to marketing management of madrasah, (1) the product is a madrasah education service that encompasses various types of madrasah institution services; (2) price is the cost of various services of madrasah institutions; (3) the place is the location of the school under question in determining the choice; (4) promotion is the promotion of madrasah; (5) human resources are those involved in madrasah services, in this case, educators and education personnel; (6) physical evidence is linked to madrasah facilities and infrastructure; and (7) the process involves all madrasah service activities. Implementation of marketing mix in madrasah institution can be modified according to condition and situation of madrasah institution. For example, the implementation of new students can be achieved before the time set by the government. The theme of the acceptance program of new students comes under the selection for entrance interests (SEI) program, which is the development of new enrollment programs. The result of the madrasah is to know the number of new students. In addition, early madrasahs can plan education services. Planning is an early stage of the marketing management of madrasah. It is a process of systematically designed marketing activities. The designed activities will be carried out to achieve the goal. The activities are (1) market identification; (2) market segmentation and positioning; (3) product differentiation; and (4) school services (Imam Machali and AraHidayat, 2016: 298). Organizing is an advanced planning in a series of marketing management. It is a marketing activity carried out by a group of people to achieve the goal. Organizing activities include the division of duties, authority, and responsibility of marketing officers of madrasah. Actuating is a series of madrasah management that realizes planning and organizing. Controlling is the process of observing and/measuring marketing management activities of madrasah. Madrasahs should set marketing strategies to include the following steps: (1) identify markets to identify market conditions and map from competing madrasah; (2) market segmentation and positioning to divide the market into a group of buyers; (3) product differentiation to arrange different programs with other madrasah; (4) madrasah marketing communication involving academic and nonacademic activities; and (5) madrasah service. In the context of education, to win the competition, it can apply the marketing mix strategy, in this case known as 7P (product, price, promotion, place, people, physical evidence, and process): the product is a madrasah program that can satisfy customers; price in this context is the cost incurred by the customer; place (location) is the location of madrasah; promotion is the activity of communicating madrasah products; people (human resources) are the people involved in the madrasah program; physical evidence is the decisions; and process is the process of madrasah program. The marketing management of a madrasah that implements the marketing mix can change the image of the community to the madrasah. The role of madrasah in the society is inevitable. As image changes, madrasah constantly improves the service quality, so that it can compete with public schools, to finally become the number one educational institution of interest to the public. 


\section{CONCLUSION}

1. Madrasah should improve madrasah management in general and marketing management in particular.

2. Madrasah should focus on madrasah marketing management.

3. Marketing strategy must be set to focus on customer satisfaction.

\section{REFERENCES}

FandyTjiptono. 2009. Service Marketing. Yogyakarta: Jelajah Nusa.

SofjanAssauri. 2010. ManajemenPemasaran. Jakarta: Raja Grafindo Persada.

Imam Machali. 2017. AntologiPemikirandanManajemenPendidikan. Yogyakarta: UIN Sunan Kalijaga.

Imam MachalidanAraHidayat. The Hanadbook of Education Management. Jakarta: Prenadamedia Group.

Philip Kotler. (1997). ManajemenPemasaran. Marketing Management 9e. Indonesian Language Edition, Volume 1. By Prentice-Hall. Inc. A. Simon \& Schuster Company. Upper Saddle River, New Jersey 07458 (h. 36).

Fajar, Malik. Madrasah dantantanganModernitas, Mizan, Bandung. 1999.

- Sheila, Kessler. Measuring and Managing Customer for Educational Institution. 2nd Edition. New Jersey: Prentice-Hall, Inc. h. 25.

Creswell, John. (2015). Riset Pendidikan. Perencanaan, PelaksanaandanEvaluasi Riset Kualitatifdan Kuantitatif. Fifth translation edition. Yogyakarta: Pustaka Pelajar.

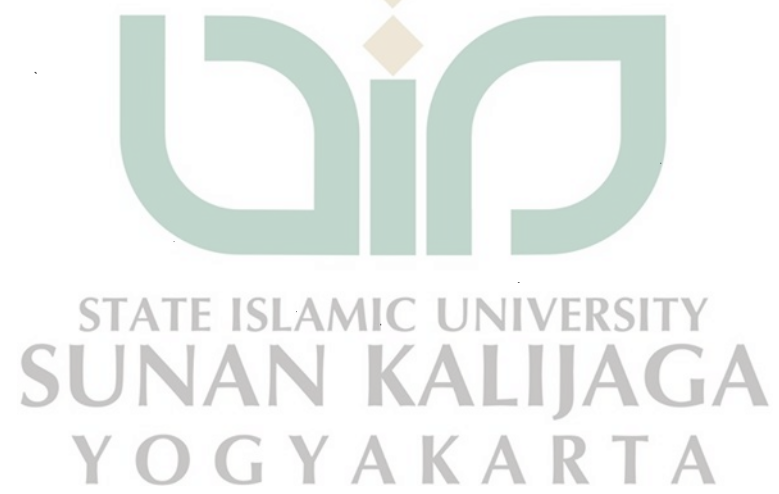




\section{Author index}

Ablaev, I.M. 97

Ahmad, A.R. 89

Andreeva, I.N. 145

Artamonova, E.G. 139

Auysheeva, N.N. 103

Awang, M.M. 89

Badyina, K.Y. 185

Badyina, K.Yu. 159

Bakhtin, A.G. 165

Bakhtina, V.V. 165

Baklanova, T.Y. 103

Baranovich, D.-L. 131

Bazhenova, N.G. 219

Biryukova, N.A. 275

Blinova, M.L. 269

Borisova, E.Y. 171, 175

Bosova, L.L. 257

Boyarinova, G.N. 211

Carnia, E. 65

Chaldyshkina, N.N. 245

Chetthamrongchai, P. 1

Chew, F.P. 25, 33, 89

Chin, K.-Y. 57

Choi, H. 313

Danilova, O.V. 171

Daryakin, A.A. 81

Demchenko, M.V. 193

Dorogova, J.A. 283

Dremina, I.E. 181

Egoshina, R.A. 219

Fliginskikh, E.E. 185

Gavrilov, A.M. 265

Gavrilova, M.N. 197

Ghanieah, N. 75

Glukhova, N.N. 203, 211

Golovina, N.N. 159
Grunina, S.O. 245

Guseva, E.V. 203

Hamad, Z.H. 25

Hamzah, M.F.B. 321

Han, C.C. 131

Hong, Z.-W. 57

Hrbackova, K. 337

Hsiao, H.-Y. 57

Hussain, M.N.B.Md. 321

Hutagalung, F. 25, 75, 131

Ivanova, I.G. 219

Jatmika, H.M. 149

Kadykova, G.N. 211

Kairupan, S.B. 289

Kannan, P.M. 297

Karandaeva, T.A. 171

Kazakovtseva, M.V. 225

Kazarenkov, V.I. 275

Kazyro, G.N. 251

Khaptakhaeva, N.B. 103

Khydyrova, A.V. 139

Kim, G. 313

Kim, Y. 305, 313

Kolesova, T.V. 237

Kolomiets, D.I. 275

Kom, M. 41

Korableva, S.V. 181

Korotkov, S.G. 231

Kozina, I.B. 171, 175

Kozlova, N.N. 117

Krasnova, N.M. 203

Krylov, D.A. 231

Kurapova, I.A. 181

Kuzminykh, Zh.O. 165

Lavina, T.A. 257

Lavrentiev, S.Y. 231

Leng, C.H. 75
Lezhnina, L.V. 181

Li, L.P. 131

Lim, C.T. 33

Loskutovan, E.A. 283

Lumban Gaol, F. 41

Maksimov, V.N. 203

Mamedova, N.A. 139

Marthandan, G. 297, 329

Martínez-Arroyo, J.A. 7, 15

Mironova, M.D. 111

Mitrofanova, T.A. 237

Mukhina, S.A. 197

Munastiwi, E. 155

Naykhanova, L.V. 103

Ndii, M.Z. 65

Nesterov, V.N. 117

Oh, Y. 305

Petukhova, O.A. 245

Polozova, O.V. 197

Rahman, A.A.A. 89

Rathimala, K. 329

Romanova, E.V. 237

Romanova, M.S. 237

Rosli, N.A. 75

Rouiller, N. 193

Ruchkina, G.F. 193

Rusinova, N.V. 219

Rybakov, A.V. 159

Sabitova, N.M. 125

Semenova, G.N. 185

Sendouw, R.H.E. 289

Shalaeva, S.L. 245

Shamtieva, M.R. 145

Shasheela Devi, K. 329

Shavaleyeva, C.M. 125

Shcheglova, N.N. 145 
Shishkina, O.V. 269

Shkalina, G.E. 211

Si, S. 41

Sinagatullin, I.M. 275

Sirazetdinov, R.M. 111

Sokolova, G.L. 251

Soldatkina, T.A. 251

Streltsov, R.V. 257

Sudharatna, Y. 1

Sujarwo 149

Sumaryanti 149

Supriatna, A.K. 65

Susanto, B. 41

Svetlova, V.A. 159
Timerkhanov, R.S. 125

Timofeev, V.V. 265

Toktarova, V.I. 261

Tomoliyus 149

Tsaregorodtsev, E.I. 225, 257

Ustymenko, O.N. 283

Utama, B. 149

Valenzo-Jiménez, M.A. 7, 15

Vengerovskiy, E.L. 193

Villa-Hernández, L.A. 15

Virtsev, M.Y. 111
Vissarov, A.V. 265

Volkova, T.A. 145

Wang, G. 305

Yagdarova, O.A. 165

Yakovleva, S.L. 185, 251

Yalalova, N.F. 81

Yambaeva, N.V. 283

Yarygin, A.A. 265

Zabolotskikh, O.P. 269

Zagainov, I.A. 269

Zimina, I.S. 197

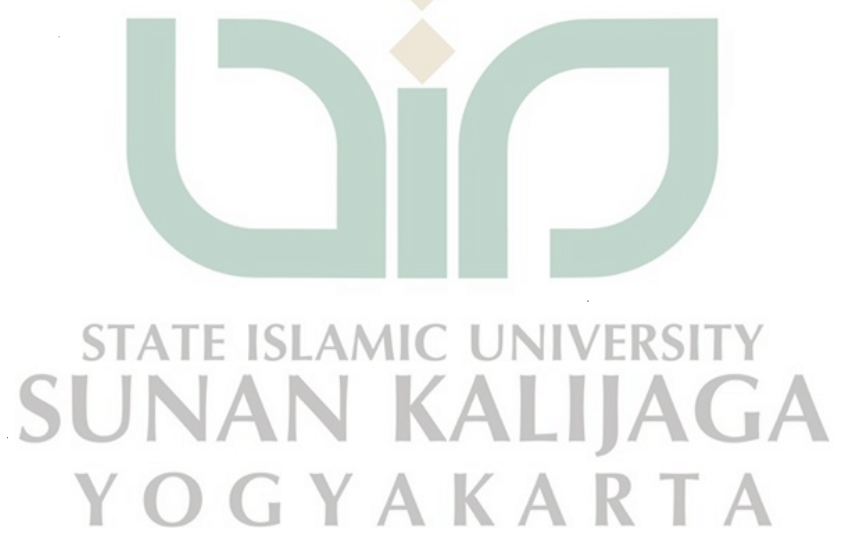


